8

\title{
Recognition dynamics and Lebanese Hezbollah's role in regional conflicts
}

\author{
Hanna Pfeifer*
}

\section{Introduction}

On 3 January 2020, Iranian general Qassem Soleimani was killed in a US drone strike in Baghdad in a targeted killing operation. Besides being a general in the Iranian military forces, he is also considered to have been the second most important political figure in Iranian leadership after Ayatollah Ali Khamenei. At the same time, however, he was the head of the Islamic Revolutionary Guard Corps's (IRGC's) Quds Force (QF). While the QF had been sanctioned as a terrorist entity since October 2007, it was only the Trump administration that put the IRGC on the list of terror organisations in April 2019. ${ }^{1}$ Iran immediately responded by designating US military forces a terrorist entity. ${ }^{2}$

Observers have warned against the consequences of such listings for state sovereignty and political legitimacy. ${ }^{3}$ Some perceive the upholding of Iran's recognition as a state and simultaneous mis-recognition of its armed forces as a terrorist organisation to be a severe disruption of previously established inter-state practices. But the case may not be so unique after all. This chapter argues that similar patterns of hybrid recognition practices can also be found in the case of Lebanese Hezbollah. It explores how the recognition of Hezbollah as a somewhat legitimate part, or at least a major player, of Lebanese society and Middle Eastern politics and simultaneous mis-recognition as a transnational terrorist organisation influence conflict dynamics in the region. It analyses Hezbollah's recognition claims directed at three different audiences, that is, the Lebanese people, regional actors and publics, and the international community and particularly Western states, and traces Hezbollah's discursive strategy with regard to acts it perceives as mis-recognition. It thereby aims at investigating how hybrid recognition practices may impact armed non-state actors' (ANSAs') identity construction and, in the long run, conflict dynamics. 
By hybrid recognition, I refer to the simultaneous occurrence of recognition and mis-recognition practices by different granters, but sometimes also by one and the same actor. Depending on the respective recognition-granter, Hezbollah's recognition may be more (Lebanese domestic context, population in the Arab world) or less (global context) 'thick' (Allan and Keller 2006; see introductory chapter to this volume). Moreover, recognition practices change over time (Biene and Daase 2015); addressees of recognition claims may gradually grant, but also withdraw recognition. Following the editors' conceptualisation, mis-recognition is understood as humiliation, disrespect or false representations of a collective identity, where the labelling as a terrorist organisation is one possible form (see also Dudouet in this volume). Finally, and this is particularly relevant with regard to Hezbollah, I understand an ANSA's identity and the practices of recognition with which it is met as mutually constitutive. This means that claims to the recognition of a certain identity may be rejected or acknowledged, which feeds back into how an ANSA (re-)casts its identity. Conversely, recognition-granters may actively label an ANSA, thereby trying to (re-) shape or undermine its identity, which may or may not entail a reframing of recognition claims on the part of the recognition-seeker. The most important label in the case of Hezbollah is 'terrorism', but 'sectarianism' and 'foreignness' (see also Toros and Sugal in this volume) play an important role, too.

The chapter does not attempt to position itself in terms of an 'objective' classification of Hezbollah but focuses on the discursive struggles over what this ANSA wants to be recognised, and is recognised, as, and how that plays out in conflict dynamics. Notably, this also means that Hezbollah's characterisation as a 'hybrid' actor (Azani 2013) in the academic literature is not taken as a given ontological quality, but rather as a product of a political power-play (Armborst 2017) or, more specifically, hybrid recognition dynamics. While the chapter also takes into account reactions (formal and discursive acts) of recognition-granters, its main empirical focus is the recognition claims put forward by Hezbollah as a recognition-seeker, as well as its reactions to recognition-granting and -denying, and mis-recognition (discursive acts).

The chapter briefly touches upon Hezbollah's emergence and historical development, as they are at the basis of its contemporary recognition claims. The main section is divided into three parts, each of which addresses Hezbollah's recognition claims as formulated vis-à-vis different (potential) recognition-granters (1) in Lebanese society, (2) in the Middle East and (3) among a global audience, in particular Western states. The final section summarises the results and sketches out implications for local and regional conflict dynamics. 


\section{Hezbollah between ANSA and Lebanese party}

Lebanese Hezbollah emerged in 1982, that is, in the middle of the Lebanese civil war. While its foundation was directly linked to Israel's invasion of the Lebanese South, it needs to be put in the broader context of Shiite social mobilisation in the 1970s which, among others, spurred demands for more political rights in the sects-based Lebanese political system. This politicisation was reinforced by Shiite clerics who had been sent to hawzat (Shiite seminaries) in Najaf (Iraq) and Qom (Iran) and introduced an activist, revolutionist spirit to the movement. In 1978, with the mysterious disappearance of its founder Musa as-Sadr, the Shiite movement lacked a unifying religious-political leadership and experienced a split into two camps. On the one hand, some within the leadership were following a secular and rather moderate path of internal reform and change of the Lebanese state and regime. On the other hand, a militant wing called for violent resistance against foreign aggression, emphasising the necessity of individual sacrifices and social solidarity. After the Islamic revolution in Iran in 1979, a few hundred Iranian Revolutionary Guards were sent to Lebanon in order to support the emerging Islamic militants in their fight against Israel and spread the teachings of the Islamic revolution (Azani 2011: 47-74). It is from this milieu that Hezbollah emerged.

Officially founded in 1982, Hezbollah only consolidated with its Open Letter Addressed to the Oppressed in Lebanon and the World in 1985 (Alagha 2011: 39-55). At this point, Hezbollah's platform revolved around resistance to the Israeli occupation of Lebanon and Palestine, as well as to any kind of oppression, emphasising 'its identity as an Islamic jihadi movement struggling to address and redress the injustices that the oppressed suffer ... irrespective of their color, race, or religion' (Alagha 2011: 16). This idea of solidarity addressed mainly those in the Global South suffering from the US-USSR struggle for influence, both of which were perceived as hegemonic powers. Finally, the letter called for establishment of an Islamic state along the Iranian model.

While the ideas of resistance (moqawama) against occupation and struggle against oppression remained at the core of Hezbollah's programme, it changed other parts of its platform. In 1992, Hezbollah had decided to enter the Lebanese political system as a party. This came to be known as the infitah (opening-up) policy and the 'Lebanonisation' of Hezbollah (Alagha 2011: 160, 188-189). Its new secretary-general, Hassan Nasrallah, pursued the path of political inclusion and prepared the party for elections. He put an emphasis on Hezbollah's rootedness in Lebanese society, thereby countering the claim that it was an 'imported' phenomenon, and foregrounded the movement's priority: resistance against Israel. Hezbollah obtained eight 
parliamentary seats and thus had considerable success in the elections of 1992. In 2009, Hezbollah issued a new Manifesto which shifted some of the Open Letter's foci. It developed a more nuanced stance towards European countries, warning them against US leadership and encouraging them instead to embrace a 'moderate drift' (quoted in Alagha 2011: 31). Moreover, Hezbollah formally declared a refrain from pursuing an Islamic state in Lebanon. Instead, it called for a strong state which would eventually abolish political sectarianism.

Besides this political reorientation, Hezbollah kept pursuing its resistance agenda, primarily targeting the Israeli Defence Forces (IDF) in Lebanon, but also was a party to the conflict in the Lebanese civil war which ended in 1990. The post-war Taif Agreement (1991) stipulated the disarmament of all non-state militias. However, Syria was able to put through Hezbollah's exemption from this. Rather than being treated as a militia, Hezbollah was declared a resistance movement and thus a necessary force to end Israeli occupation which was allowed to keep its weapons (Salem 2017: 1522-1524). Against the Taif Agreement's provisions regarding the withdrawal of foreign forces, Israeli and Syrian occupation forces remained in the country. Even though the document called for "fully eliminating the Israeli occupation' with the support of forces of the United Nations Interim Force in Lebanon (UNIFIL), Israel would not retreat until 2000. Hezbollah pursued its violent resistance over the following years and many parts of the Arab world accredited Hezbollah with the success of the eventual Israeli withdrawal (Salem 2017: 1530). It put an end to occupation - except for a piece of land in the Golan Heights, the Shebaa Farms, which Lebanon claims as belonging to its national territory. Still today, this serves as a justification for Hezbollah's continued activity as a militant, armed resistance. Few Lebanese voices raised doubts about this state of affairs (Azani 2011: 173). Except for minor episodes of violence in the Shebaa Farms, the period from 2000-2006 can be qualified as relatively calm.

Syrian forces, too, remained on Lebanese territory. Tensions over their continued presence grew stronger in Lebanese society in the early 2000s. In addition, with the beginning of the 'global war on terror', international pressure rose, given that the US had denounced Syria as being part of 'the axis of evil'. Supported by the US and France, then-prime minister Rafiq al-Hariri formed an inter-sectarian, anti-Syrian alliance in Lebanon. In 2005, Hariri and more than twenty other persons died in a massive car bomb explosion in the centre of Beirut. As many Lebanese anti-Syrian politicians and large parts of the population, as well as international actors, suspected Syria and Hezbollah to be directly involved in the attack, pressure on Syrian forces to leave Lebanon became still higher. On 14 March, more than one million people demonstrated against the Syrian occupation of Lebanon in 
Beirut's Martyrs' Square. Six days earlier, that is, on 8 March, Hezbollah and allied groups had organised a protest supporting the Syrian presence. In April, this culminated in anti-Syrian protests and the withdrawal of Syrian forces after twenty-nine years of occupation (Salem 2017: 1531-1534).

The political landscape after the Cedar Revolution was marked by the polarisation between two blocs, the March-14 and the March-8 Alliances, giving rise to 'a new cleavage in Lebanon in which political contestation ... takes place' (Nagle 2016: 1149): They cut across the classical sectarian boundaries between Muslims and Christians, but have created new tension between Sunnis and Shiites. This tension is reinforced by the regional support for both groups, with Saudi Arabia assisting the Sunni Future Movement and Iran supporting Hezbollah and, to a lesser degree, Amal. The assassination of Hariri and the subsequent revolution also had international ramifications. In 2007, the UN Security Council adopted resolution 1757, thereby creating the Special Tribunal for Lebanon (STL) which aims at investigating the Hariri assassination and whose work is still ongoing.

Meanwhile, occasional border incidents escalated in July 2006. Hezbollah militants attacked a patrol on Israeli soil, killing three and capturing two Israeli soldiers. The IDF launched what came to be known as the July War, leaving over 1100 Lebanese and over 40 Israeli civilians dead and several hundreds of thousands of people displaced in both countries. The Lebanese South as well as the Dahiyeh were devastated (Norton 2014: 132-143). Despite the success of Hezbollah in fighting back against the IDF, debates in Lebanon about the power of Hezbollah and the question of disarmament re-emerged, and tensions grew to a new level in 2008. Under the leadership of Rafiq al-Hariri's son Saad al-Hariri, the Lebanese government decided to investigate Hezbollah's independent telecommunications system with the purpose of removing it. Hezbollah reacted by blocking the road to the airport and seizing control over West Beirut. Both the prime minister's private militia and the Sunni-dominated Internal Security Forces could not defy Hezbollah and allied armed groups. Fearing an internal sectarian split, the military forces did not intervene in the conflict.

The period of analysis for this chapter begins with the Arab uprisings of 2010 and 2011 as experienced by many of the Middle East and North Africa (MENA) republics. It coincided with the collapse of the national unity government in Lebanon that Saad al-Hariri had formed in 2009. In reaction to the first indictments issued by the STL against Hezbollah members, eleven ministers from the March-8 alliance resigned. In June 2011, a new government was formed - without the participation of March-14 and allegedly dominated by Hezbollah, which had two ministers in the cabinet (Fakhoury 2016: 24-25). Not even two years later, this government collapsed and was followed by a new national unity government, putting an end to ten months 
of political stalemate (Wählisch and Felsch 2016: 5). After years of negotiations over the new Lebanese president, parties finally reached an agreement that involved yet another re-formation of government at the end of 2016, with Saad al-Hariri becoming prime minister again. Under massive antigovernment protests, the cabinet resigned in October 2019. This most recent popular uprising is directed against the political class as a whole, thereby transcending both sectarian dividing lines and the March-8-March-14 alliance logic. As of February 2020, protests are continuing, despite the formation of a supposedly 'neutral' technocratic government under the independent prime minister Hassan Diab in January $2020 .^{5}$

\section{Hezbollah's recognition claims vis-à-vis different recognition-granters}

For the breadth and diversity of its repertoire, Hezbollah has sometimes been called a 'hybrid terrorist organisation' because it has 'three complementary, related areas of activity: da' $w a$ and social welfare, military resistance (jihad), and political activity' (Azani 2013: 902). Indeed, the three areas of activity go hand in hand with recognition claims addressed to at least three audiences: first, the Lebanese people, particularly the Shiite community, and political adversaries and allies; secondly, on the regional level, Arab publics, like-minded resistance movements, and Arab states and governments; and finally, a global audience. Hezbollah's recognition claims refer to its own identity, its claim to representing the Shiite community in Lebanon and the interests of an imagined Arab-Islamic community in the broader Middle East, as well as the legitimacy of their resort to violent means, in particular in contrast to other actors' use of force.

The analysis is based on sixty-five speeches by Secretary-General Hassan Nasrallah between 2011 and 2016, as well as interviews conducted in 2014 and 2015 with Lebanese journalists, think-tank members, researchers, and representatives of research and media institutions close to Hezbollah. The study focuses on Nasrallah because he is Hezbollah's clear and uncontested leader, and sets the tone in both political and military affairs. Other voices from within the party are present, but do not challenge Nasrallah's views. Rather, they are in line with the official party platform as defined by Nasrallah, which is one indicator of the party's strictly hierarchical organisation. The empirical study is a discourse analysis. Mis-recognition as perceived by Hezbollah can be identified whenever there is an emphatic, sometimes even emotional discursive act of rejection, directed against claims about identity, acts and goals 'falsely' attributed to Hezbollah. Those are usually followed by positive recognition claims which aim at correcting the misrepresentation. Sometimes, however, recognition claims are formulated 
more proactively, without being a direct reaction to an act of perceived mis-recognition.

\section{Domestic recognition games: between Lebaneseness and resistance exceptionalism}

Hezbollah's recognition claims in the Lebanese context address two audiences: the Shiite community and its own supporters, and the general Lebanese public, including political adversaries. The latter audience is more prominent in Nasrallah's speeches. The main recognition claim concerns Hezbollah's cause: the necessity and legitimacy of resistance against Israel and, more generally, oppression. Derived from this are three interlinked recognition claims regarding Hezbollah's identity as an actor: it wants to be recognised (1) as a genuinely Lebanese actor; (2) as a non-sectarian, honest and constructive political player; and (3) as the defender of the Lebanese people.

The Lebaneseness of Hezbollah is a recurring theme in its discourse and addresses three forms of mis-recognition. The first is the allegation that Hezbollah is controlled from outside and part of a would-be 'Shiite expansion' (Nasrallah 2012a) project led by Iran that supposedly aims at Shiite dominance in Lebanon, Yemen, Palestine and Iraq. According to Hezbollah, the goal behind the narrative of the Shiite crescent, the demonisation of Iran as a global threat and the misrepresentation of Hezbollah as its puppet is to instigate intra-Muslim tensions and incite Sunnis against Shiites, as well as Arabs against Persians. Secondly, Hezbollah's adversaries regularly present it as a globally operating terror organisation whose agenda reaches far beyond the Lebanese and Middle Eastern context. For instance, it was claimed that Hezbollah's military activity covered places like Iran, Libya, Yemen, Bahrain, Egypt, India, Georgia, Thailand, Latin America, West Africa and Azerbaijan as well as Bulgaria. Nasrallah's reactions to these claims used humour in order to display their absurdity: 'If only we were as such. ... If only we had this expansion and presence. That would have made us feel strong and efficient' (Nasrallah 2012c). Finally, Hezbollah also feels mis-recognised as an actor that operates with a secret agenda to take over the state and Islamise Lebanon, pulling the strings of government behind the scenes. According to Nasrallah (2015d), this 'psychological warfare' is waged by parts of the March-14 bloc, but also the media, and is supported by Israel and America who spend huge amounts of money to harm the reputation of Hezbollah and the resistance, and to mislead public opinion.

Against these allegations, Hezbollah emphasises, first, that it is a genuinely Lebanese actor that acts in the interest of the Lebanese nation, has for a long time abandoned its agenda to establish an Islamic state, and 'entered 
deeper into the Lebanese status quo' (Nasrallah 2012a). It insists on democratic, legitimate political institutions and has a firm belief in democratic procedures. Secondly, Hezbollah seeks recognition for its role as an honest and constructive political partner with a decidedly anti-sectarian agenda. Nasrallah regularly expressed sympathy for fears of other religious communities, especially in the context of reforming the Lebanese electoral system and against the backdrop of increased sectarian violence in Syria. Despite the respect for religious pluralism in Lebanon, Hezbollah has the vision to build one Lebanese 'community and ... a nation as a prelude for building a state for it later on' (Nasrallah 2012a), eventually abandoning the sectarian basis of Lebanese politics. As proof of these intentions, Nasrallah points to Hezbollah's demonstrated willingness for dialogue and compromise with political adversaries. It thereby seeks to prove that it is a rational, ethical and responsible actor, an honest broker for Lebanese interests. The basis for this ethical stance is a commitment to truthfulness, which is at the core of Nasrallah's public image. He presents himself and, indeed, is widely perceived as a man who is capable of logical argumentation and clear-sighted political analysis, and who keeps his word (Interviews 1 and 2).

Finally, Hezbollah clearly identifies armed resistance as the one field where there is no room for concessions or negotiation. Being recognised as a defender of Lebanese sovereignty against Israel's aggressions and, later on, what Hezbollah calls the 'Takfirist threat' spilling over from Syria is the most important claim the party makes vis-à-vis the Lebanese public (Nasrallah 2014a, 2015e, 2016b). It calls upon the Lebanese to acknowledge the (Islamic) resistance's success in restoring the rights, land and dignity of the Lebanese people against the Israeli invasion and occupation. Neither the Lebanese army nor UNIFIL had been capable of protecting Lebanon in the past. In this situation, the resistance stepped up and took over the task of Lebanese self-defence. Even though the Israeli occupation ended in 2000, its massive attacks in 2006, as well as the fact that it still occupies the Shebaa Farms, are manifestations of the persistent Israeli threat, which makes continued resistance indispensable. In 2013, Nasrallah also added 'Takfirism', that is, Salafi-jihadi groups such as ISIS, to the resistance's list of enemies and its agenda of self-defence, portraying it as an imminent threat to all Lebanese.

Emphasising the non-sectarian, patriotic character of the resistance is central to Hezbollah's recognition claims vis-à-vis the broad public: solidarity with the resistance is part of the Lebanese nation-building project. This does not mean that everyone has to fight - even though there is a multi-confessional brigade within the resistance (Alagha 2011: 160, 188-189) -, but rather support it mentally and morally. At the same time, however, Nasrallah also seeks recognition for the main burden the resistance carried in defending 
the country and the sacrifices that were made by the Shiite community. Its 'steadfastness' and 'courage' (Nasrallah 2015a) brought Lebanon liberation and peace, 'which all the Lebanese are enjoying, regardless of having paid the price for it or not' (Nasrallah 2014a). The oscillation between both arguments, that is, the trans-sectarian nature and deep anchoring of the resistance in the broad population, and the tribute to the Islamic resistance and gratefulness towards the Shiite community, is an expression of Hezbollah's struggle to gain legitimacy among all the Lebanese and keep up the resistance spirit among its own adherents and fighters. This became significantly more difficult with its military engagement in Syria (see next section).

Besides emphasising the immediate security interests of all Lebanese being jeopardised by the conflict dynamics in Syria, one discursive strategy Hezbollah employed was to regularly evoke the so-called 'army-people-resistance formula' (Nasrallah 2011b). As the army is not strong enough to defend Lebanese sovereignty, and the state has proven to be too naïve to recognise and effectively tackle external threats from early on, Hezbollah, as an auxiliary, regularly steps up to support the army in its efforts. This burden-sharing is completed by the popular resistance, which refers to 'laymen' that are willing to protect their country and people against hegemonic schemes, side by side with the army and the organised resistance. At the same time, however, Nasrallah calls for an enhancement of the military's strength, so as to make the resistance's support dispensable in the future. This goes hand in hand with Hezbollah's urges to build a stronger Lebanese state. But this claim is yet another manifestation of the hybrid character of recognition practices around Hezbollah. While it does seek recognition as a legitimate and somewhat normal part of Lebanese politics, as well as a 'patriotic' defender of national interests and sovereignty, Nasrallah regularly detaches Hezbollah from the Lebanese state, which he portrays as weak, sometimes as corrupt and inefficient, and as based on precarious sectarian foundations. He seeks recognition for Hezbollah's autonomy, not least in taking such decisions as intervening in neighbouring Syria, keeping its weapons and communication systems, and getting involved in regional politics as a non-state actor. Separating itself from the state in this way not only ignores the ways in which Hezbollah contributes to undermining state authority and power itself. It is also a way of absolving itself from the responsibility of implementing effective policies, even though Hezbollah has been part of the government over the whole period between 2011 and 2016. In a way, it is Hezbollah's ambiguous recognition claims that are answered with similarly ambivalent (discursive) acts of recognition and mis-recognition: its adversaries, notably from the March-14 bloc, cooperate with it pragmatically on an everyday basis, but still engage in discourses that portray Hezbollah as an outsider, threat to Lebanese security or transnationally rooted terrorist actor. This 
phenomenon of hybrid recognition claims and responses is even more pronounced on the regional level.

\section{Regional recognition practices: between defender of the oppressed and terrorist organisation}

On the regional level, Hezbollah seeks recognition from two main recognitiongranters: (1) Arab and Muslim publics in the MENA and (2) state actors. In both cases, it tries to portray itself as a core part of the transnational resistance against Israel and, more generally, oppression and hegemony, and thus the (only remaining) honest broker for Arab and Muslim interests. When Nasrallah addresses the people of the region, he tries to gain recognition for Hezbollah as a core part of the axis of resistance. It consists of two 'steadfast' countries, Iran and Syria, that have not submitted to the international pressure of normalising relations with Israel, as well as the armed resistances in Lebanon and Palestine (Hamas). To Nasrallah, the axis of resistance is the only defender of Arab sovereignty in the face of Israeli aggression, the continued occupation of Palestine as the Arab-Muslim cause, and global hegemonic schemes devised for the broader region. While the focus of Hezbollah's activity within the axis of resistance used to be the fight against Israel, two additional causes were added in the aftermath of the Arab uprising and subsequent regional dynamics: the struggle against oppressive Arab regimes and the fight against 'Takfirism'. For Hezbollah, both are at the core of Arab-Muslim shared interests.

The Israeli occupation and the deprivation of Palestinians' rights are simultaneously a humiliation of all Muslims and Arabs. This is why the only legitimate choice is resistance; any government in the MENA should be judged according to its stance on the Palestinian cause which is 'the ruling norm in this time' (Nasrallah 2012b). It is governments' obligation to show solidarity with the transnational resistance. However, the only countries to have constantly supported the struggle, even in times of severe crisis and pressure, are Iran and Syria. According to Hezbollah, without their financial support, weapons deliveries and unconditional solidarity, neither the Lebanese nor the Palestinian resistance could have achieved success. Hezbollah thus seeks recognition as the key actor of the resistance, but also for the Palestinian question as the one true Arab and Muslim cause. Calling for solidarity among Arabs and Muslims, Nasrallah (e.g. 2012b) also wants them to acknowledge the merits Hezbollah has in fighting for this common cause without asking anything in return. Its military success is all the more laudable as it is the only Arab actor ever to have defeated Israel.

While this role as 'the last man standing' against the common enemy has always been central to Hezbollah's discourse, the Israeli-Palestinian conflict 
became relatively less important once the Syrian civil war started. As soon as the Arab uprisings began in late 2010, Hezbollah needed to formulate a position on the popular protests and, later in 2011, the ousting of some of the authoritarian leaders. Nasrallah interpreted the events not only as a popular demand for freedom, but also took them as an expression of Arabs' discontent with the regimes' submissiveness to Israel and abandonment of the Palestinian cause. Both motivations deserved Hezbollah's full solidarity, and thus Nasrallah lauded the Tunisians, Egyptians, Bahrainis, Yemenis and Libyans for their courage and readiness to sacrifice for the revolutions. He also expressed the hope that successive leaders would strengthen the resistance and allow for 'Iran and Syria to gain new allies, advocates and members in this axis' (Nasrallah 2011b). But it turned out that the Israeli-Palestinian question would not be prominent on the agenda of new or old political elites. Rather, some of the post-uprising societies were drawn into civil wars - a development for the ummab which, according to Nasrallah, 'is the most dangerous situation ever since the occupation of Palestine' (Nasrallah 2014b).

Hezbollah's stance on the uprisings was more ambivalent when it came to the Syrian situation. Initially, it insisted that the Assad regime was trying to establish political dialogue and push for reform. But these efforts were undermined by the interests of international actors. According to Nasrallah, and as opposed to the situation in other countries, there was a Western-Israeliled and Gulf-supported agenda to topple the Syrian regime so as to break the axis of resistance. Imposing war on the country was part of this plan. As a consequence, Hezbollah came to a different judgement for Syria than with regard to other countries affected by the Arab uprisings. Both the regime's supposed will for reforms and its merits in supporting the Palestinian cause justified Hezbollah's continued support for Assad: 'Syria has been the cherisher of the Resistance, so the Resistance can't stand still while that cherisher is being ruined' (Nasrallah 2013). Against this backdrop, Hezbollah's attempt to be recognised by the peoples of the region as the voice - and hand - of the oppressed against oppressors became increasingly implausible. While it had tried to show itself as the advocate of the people who had been oppressed by their own governments for years, its stance on Syria made this narrative increasingly hard to sell.

This became even clearer after Hezbollah had officially started intervening in the Syrian conflict in spring 2013, at the request of the regime. At that point, it had become clear to the party that 'the Takfiri current is dominant among the Syrian opposition' (Nasrallah 2013). In this initial phase, Nasrallah claimed that an intervention became necessary, first, because solidarity with the Syrians had to be demonstrated and the axis of resistance needed to be protected. Nasrallah also tried to establish a tight link between the survival of the Syrian regime and the struggle for Palestine, and thus the resistance project 
in the narrow sense: 'For sure the road to al-Quds [Jerusalem] passes through Qalamoun, Zabadani, Homs, Aleppo, Daraa, Sweidaa and Sasakeh ...; that's because if Syria is lost, Palestine would be lost too' (Nasrallah 2015e). Secondly, Hezbollah emphasised that Lebanon's security was jeopardised by potential spill-overs from its neighbour country. Indeed, several border assaults by Syrian rebel groups, and particularly jihadi groups, occurred in 2013 and 2014. Through these arguments, Hezbollah sought recognition, yet again, as a defender of Lebanese sovereignty among its compatriots, but also as a firm believer in, and protector of, the resistance project against Israel. The latter claim was directed at the broader Arab public, but also a signal to Iran and Syria that they could count on Hezbollah.

In contrast to this narrative, Hezbollah's Lebanese adversaries claimed that its military engagement had given rise to jihadi attacks on Lebanon in the first place. But critics increasingly also emerged from within the Shiite community. This is why Nasrallah shifted the focus of justification to the fight against 'Takfirism' as a global threat against the Muslim ummah and the Middle East as a whole. He portrayed Hezbollah as the only clear-sighted actor that had understood and acted upon the 'Takfiri' threat. The severity of this danger called for joint action in Syria and Iraq, and Nasrallah encouraged fellow Muslim actors and Arab states to support Hezbollah in fighting ISIS and other Salafi jihadists. But even if no one were to respond to these calls, Hezbollah would always be 'assuming this responsibility on both levels', that is, against Israel and the 'Takfirists' (Nasrallah 2015f).

In that sense, Hezbollah tried to gain recognition as a responsible actor that engaged in Arab self-defence where necessary. In 2014 and 2015, when ISIS had risen to the top of the global security agenda, Nasrallah increasingly made the case that fighting 'Takfirism' was not only a matter of security for the whole region, especially the Levant, but also elevated it to a religious duty. Protecting the Muslim ummah, Shiites as much as Sunnis, as well as Islam itself against terrorists was declared a priority. However, actors such as ISIS also threatened the broader cultural and political make-up of the region and the people living in it, 'their civilization, their history, their diversity, their right to live a dignified peaceful life, their right to partnership, and their right to free expression' (Nasrallah 2015f). Nasrallah tried to convey an image of Hezbollah that emphasised its non-sectarian, tolerant and pluralist nature, as well as its commitment to preserving unity among Middle Eastern peoples. To this end, he also emphasised that Hezbollah only stepped up to fulfil its 'jihadi, religious, and historic responsibilities' (Nasrallah 2016c) where it had been asked for help prior to its respective military engagements, such as in the cases of Syria and Iraq.

These attempts to be granted recognition as a non-sectarian and nondivisive actor must also be seen in the context of an increasingly hostile 
anti-Shiite discourse which was reinforced by the Gulf countries and in particular Saudi Arabia from 2015. Nasrallah's rhetoric had always been critical towards these countries, but a whole new tone was set when the Saudi-led coalition started its military intervention in Yemen in March 2015. By engaging in this brutal war, 'the Kingdom of "Benevolence"' (Nasrallah 2015c) had now started to show its real face. Nasrallah tried to reveal the intimate connection that exists between Wahhabist ideology and 'Takfirism' - and, thus, between Saudi and Salafi-jihadist practices. By this, Nasrallah aimed, on the one hand, at establishing that the situations in Yemen and Syria/Iraq should be seen as very similar, with the 'real' enemy in both cases being a child of Wahhabism. On the other hand, he also tried to put the terrorism label on both Saudi Arabia and 'Takfirist' groups. This escalation is a reaction to the discursive, but also legal mis-recognition acts pushed for by Saudi Arabia. The Gulf Cooperation Council and the Arab League had agreed to list Hezbollah as a terrorist group in early 2016. The party answered by painting an image of the 'real' terrorist connection between the Gulf and 'Takfirist' groups all over the MENA region, emerging from the same intellectual tradition and aiming at the annihilation of religious and cultural pluralism: 'The entire world is now ... well aware that all the terrorism in this world and in any corner in the world is due to the intellect and money of the [Saudis]' (Nasrallah 2016d).

Nasrallah then tried to re-embed this narrative in the broader framework of oppressors vs oppressed. He pointed out the cynicism by which such countries as Saudi Arabia and the United Arab Emirates intervened with the purpose of establishing legitimacy, freedom or democracy, reminding his audience of the authoritarian, brutal and oppressive nature of these regimes. He also painted rich rhetorical images, opposing 'a self-indulgent prince who lives in luxury' to 'a prideful, poor, oppressed, struggling and striving people' (Nasrallah 2015b), an army of cowards that 'will get the Pakistanis, the Egyptians, and the Jordanians to fight for them' (Nasrallah 2015b) to the 'bravery and courage' (Nasrallah 2015a) as well as steadfastness of the resistance movements all over the Middle East. Indeed, he also tried to gain recognition for the Lebanese model of resistance where, according to Nasrallah, the organised resistance fights side by side with the armed forces and the popular resistance (see previous section). He not only considers the effectiveness of this arrangement to have been proven in the fight against Israel and in Syria, but he also sees that the Iraqis adopted the model in their fight against ISIS and the Yemenis in the face of US-Saudi aggression. Establishing this model all over the MENA promises success in fighting off hegemonic, oppressive plans: 'This is the formula of victory. This is the deterrence formula' (Nasrallah 2015d). 
With regard to the international level, Hezbollah's recognition claims remain moderate (see also Dudouet in this volume). This can partly be explained through its listing as a terrorist organisation in most Western countries; it has been designated so by the USA since 1995 and several Western states have followed. However, it seems that Hezbollah seeks recognition from Western states, at least in some respects, too. Most of Hezbollah's discourse on international matters revolves around the West, the liberal world order and its institutions, and how they interact with regional actors and interfere in MENA affairs (Pfeifer 2017). Three recognition claims can be identified that are directed at Western recognition-granters: (1) Hezbollah wants Lebanon to be recognised as a sovereign country and its internal affairs to be respected; (2) it wants to be recognised as an actor with a legitimate cause and a commitment to rules and norms as stipulated by international law; and (3) it wants to be recognised for its success in fighting the 'Takfirist threat'. This last claim is tightly connected to the perceived mis-recognition as a terrorist group.

According to Hezbollah, Western states - in particular the US and France - constantly try to meddle with Lebanese domestic affairs. Given its weakness, the state cannot stand up against these acts of interference. One example is the establishment of the STL due to US and French pressure. But Western hegemony goes far beyond Lebanon: through bringing docile dictators to power and spreading chaos and conflict, the West tries to make Arabs 'singers and dancers' (Nasrallah 2012b). Even though Nasrallah holds that liberal norms are the product of 'political considerations' rather than expressing 'rights and values' (Nasrallah 2011a), it is noteworthy that Hezbollah has always committed to some international norms, notably regarding international humanitarian law. Since 1996, it has refrained from attacking civilians (Dionigi 2014: 157). In his assessments of the wars waged in Yemen, Syria and Iraq, Nasrallah also regularly commented on illegitimate and legitimate uses of force, often using similar argumentation to that found in just war theory (Kizllkaya 2017; Pfeifer 2017: 282-302). It is remarkable that Hezbollah sets itself clear limits on the use of violence and also regularly comments on infringements on human rights and international law as committed by other actors, including ISIS and Saudi Arabia, but also Western states. Nasrallah happily points to the hypocrisy of the West and its so-called 'universal values'. The West 'gives lectures ... on civilization, democracy and the will of the majority' (Nasrallah 2011a), yet forgets about human rights when Israel attacks Palestinians and does not 'have any problem when the ruler wears a crown [or] a turban' (Nasrallah 2012a). 
However, since it has been cooperating side by side with the Assad regime and, since its intervention, Russia in Syria, Hezbollah's commitment to human rights norms becomes more and more questionable. The void on human rights violations and war crimes committed by these actors in Nasrallah's discourse can be seen as indicating a predicament (Khatib and Matar 2014): on the one hand, Hezbollah's core interest of keeping the axis of resistance makes this cooperation necessary; on the other hand, it makes the party vulnerable to allegations of being an irrational, immoral actor whose violence is simply unjustified. But what all of this shows is that there is some desire to be recognised by an international audience as a rational actor bound by certain norms - and thus be distinguished from such actors as ISIS. Being labelled a terrorist organisation was perceived as particularly unwarranted against the backdrop of Hezbollah's fight against ISIS in Syria, which involved heavy losses. While the West only became militarily active in 2015, Hezbollah had started its armed struggle against ISIS two years earlier. But instead of showing gratefulness, the West keeps, and some Arab states started, demonising Hezbollah: '[W]e are fighting the terrorist organization which is labeled by the world as a terrorist organization. How come we are labeled as terrorists? How come we are condemned?' (Nasrallah 2016a).

For Hezbollah, the West's declared fight against ISIS should not be bought into. Rather, the US has a strong interest in bringing further chaos upon the region. They do so via their 'puppet regimes' (Nasrallah 2013) in the Gulf. The eventual goal the US and its allies pursue is, according to Nasrallah, the toppling of all regimes loyal to the transnational resistance against Israel. The international will to 'forcefully frustrate' the transnational resistance grew stronger in the post-Arab uprising era, as the US, Israel and Western states at large, and the Gulf states realised that the popular revolutions might bring about resistance-friendly regimes and thus a new 'peak of the resistance project on the level of the nation' (Nasrallah 2016b). Creating chaos could serve the counter-resistance purpose: first, the US and its allies ruin the region, in order to later reintroduce themselves as heroes and liberators 'from outside' (Nasrallah 2015d). Hezbollah's interpretation of the situation in 2016 is that there is a more or less coordinated 'US, "Israeli", Takfiri, Saudi scheme that wants to practise hegemony and control, and drive away and expel the other' (Nasrallah 2016c). While not suspecting a direct, open US involvement with 'Takfirist' groups, Nasrallah does seem to think that letting ISIS grow was a calculated risk the US took - that would later overwhelm and surprise the West. Hezbollah's discourse oscillates between, on the one hand, a claim to being recognised as something entirely different from other violent groups - especially 'Takfirist' groups - and, on the other hand, the suggestion that in the end Hezbollah does not care about what Western actors think about it, given that they are caught up in 
their hegemonic, self-interested schemes and, as a consequence, are not to be trusted anyway.

\section{Conclusion}

As this chapter showed, Hezbollah dynamically reacts to practices it perceives to be mis-recognition by developing new, or re-emphasising old, recognition claims, re-interpreting its own identity and role in conflicts, and by withdrawing recognition from actors, for example the Saudi regime. Both its claims as a recognition-seeker and the reactions by its (potential) recognition-granters are hybrid, and sometimes contradictory: they combine practices of recognition with mis-recognition.

In the Lebanese context, Hezbollah defends itself against mis-recognition as a foreign-controlled, sectarian, irrationally violent actor by emphasising its patriotism, readiness for dialogue and sacrifices made for all Lebanese in the face of external threat. Indeed, Hezbollah's discursive practices within Lebanon tend to aim at calming sectarian tensions, finding compromise and avoiding open conflict, especially with violent means. How it will react to the non-sectarian protests of 2019 and 2020 which are directed against the Lebanese political class as a whole is not yet fully clear - a new narrative needs to be found, as Hezbollah, too, is denounced as keeping up a corrupt system that has led the country into economic and social catastrophe. Seeking recognition as key actor in the transnational resistance against Israel will certainly not suffice to calm the public.

On a regional level, Hezbollah claims recognition as a core actor for the most important common Arab-Muslim cause: the transnational resistance and liberation of Palestine. Later on, it also claimed to be a forerunner in the defence of Middle Eastern civilisation and Islam against the 'Takfirist threat', thereby fighting for both pluralism and unity in the region. Confronted with an increasingly hostile anti-Shiite discourse and being labelled a terrorist organisation by its 'fellow' Arabs and Muslims, that is, several states from the Gulf and regional organisations, Hezbollah tried to establish that the real terrorist connection has its origin in Wahhabi ideology and consists of both 'Takfirist' actors and Saudi Arabia. This labelling and counter-labelling, or struggle over who is the 'real terrorist', reinforces existing cleavages between what is often perceived as a sectarian conflict between Shiites and Sunnis, but is more complex by far. Hezbollah's attempt to 'sell' its success model of the golden formula of resistance to other places in the MENA is not only a form of recognition-seeking; it can also be seen as a recipe for practically countering Western-supported, high-tech warfare as led in Yemen. In this sense, Hezbollah seeks recognition not so much for the Shiite, but 
the resistance model per se, as a form and means of legitimate struggle against hegemonic projects.

Finally, Hezbollah's recognition claims are moderate with regard to the West - certainly because its hopes of cracking the wall of Western counterterrorism policies are rather low. Still, it does want to be perceived as a rational actor that complies with certain norms and is qualitatively different from ISIS. Hezbollah's discourse oscillates between, on the one hand, a claim to being recognised as something entirely different from other violent groups - especially jihadi groups - and, on the other hand, suggesting that in the end Hezbollah does not care what Western actors think about it, given that they are caught up in their hegemonic, self-interested schemes and, as a consequence, are not to be trusted.

This oscillation is also mirrored in the diverging practices of recognition that Western actors show towards this ANSA. While the US is very clear in listing the entirety of Hezbollah, including its media outlets, as a terrorist organisation and imposes strict financial sanctions, the European position is much more mixed. Many European countries and the EU have decided to only designate Hezbollah's armed wing as a terrorist organisation, but recognise its political wing as a party and a part of the Lebanese political system. It thus keeps open a door for negotiations and transformation. However, the distinction between 'two wings' obviously matches neither Hezbollah's self-perception nor the functioning of its organisation. For instance, despite the pragmatically motivated recognition of Hezbollah as an essential part of Lebanese society, its military capabilities were significantly enhanced after 2011 (O'Sullivan 2013). At the same time, for those who list the whole organisation, the question might be of how to seek ways around the state and official Lebanese government, which Hezbollah has been part of for almost a decade now. By sidelining these institutions, the Lebanese state may be weakened further. Moreover, as the above analysis showed, practices of mis-recognition are usually met by new discursive efforts to present an alternative image. These re-interpretations of the self and how it is positioned in regional conflict dynamics are motivated by a struggle for survival through recognition, at least among some audiences. Raising pressure on actors will not lead to their submission to external recognition 'offers', that is, an acceptance of being a terrorist, an outsider, and so on. Rather, more hostile rhetoric and spirals of mis-recognition may be the consequence.

\section{Notes}

" For helpful comments on earlier versions of this chapter, I am grateful to Maéva Clément, Anna Geis and Franz Xaver Schießleder. 
1 www.state.gov/designation-of-the-islamic-revolutionary-guard-corps/; last retrieved 3 April 2020.

2 www.reuters.com/article/us-usa-iran/in-unprecedented-move-u-s-names-iransrevolutionary-guards-a-terrorist-group-idUSKCN1RK1NY; last retrieved 3 April 2020.

3 https://augengeradeaus.net/2020/01/sicherheitshalber-der-podcast-folge-23-liveusa-vs-iran-und-kampfflugzeug-der-zukunft/; https://smallwarsjournal.com/blog/ are-we-prematurely-designating-irans-revolutionary-guards-as-criminal-soldiers; www.ejiltalk.org/the-killing-of-soleimani-and-international-law/; last retrieved 3 April 2020.

4 www.presidency.gov.lb/Arabic/LebaneseSystem/Documents/TaefAgreementEn.pdf; last retrieved 3 April 2020.

5 https://foreignpolicy.com/2020/01/22/lebanons-halloween-government/; last retrieved 3 April 2020.

\section{References}

Alagha, J. (2011), Hizbullah's Documents from the 1985 Open Letter to the 2009 Manifesto (Amsterdam: Pallas Publications).

Allan, P. and A. Keller (2006), 'The concept of a just peace, or achieving peace through recognition, renouncement, and rule', in P. Allan and A. Keller (eds), What is a Just Peace? (Oxford: Oxford University Press), pp. 185-215.

Armborst, A. (2017), 'Conceptualizing political violence of non-state actors in international security research', in A. Kruck and A. Schneiker (eds), Researching Non-state Actors in International Security: Theory and Practice (Abingdon and New York, NY: Routledge), pp. 14-28.

Azani, E. (2011), Hezbollah: The Story of the Party of God. From Revolution to Institutionalization (Basingstoke: Palgrave Macmillan).

Azani, E. (2013), 'The hybrid terrorist organization: Hezbollah as a case study', Studies in Conflict \& Terrorism 36:11, 899-916.

Biene, J. and C. Daase (2015), 'Gradual recognition: curbing non-state violence in asymmetric conflict', in C. Daase, C. Fehl, A. Geis and G. Kolliarakis (eds), Recognition in International Relations (Basingstoke: Palgrave Macmillan), pp. 220-236.

Dionigi, F. (2014), Hezbollah, Islamist Politics, and International Society (New York, NY: Palgrave Macmillan).

Fakhoury, T. (2016), 'Lebanon's consociational politics in the post-2011 Middle East: the paradox of resilience', in M. Felsch and M. Wählisch (eds), Lebanon and the Arab Uprisings: In the Eye of the Hurricane (Abingdon and New York, NY: Routledge), pp. 21-30.

Khatib, L. and D. Matar (2014), 'Conclusion: Hizbullah at a crossroads', in L. Khatib, D. Matar and A. Alshaer (eds), The Hizbullah Phenomenon: Politics and Communication (New York, NY: Oxford University Press), pp. 181-190.

Kizılkaya, Z. (2017), 'Hizbullah's moral justification of its military intervention in the Syrian civil war', Middle East Journal 71:2, 211-228.

Nagle, J. (2016), 'Between entrenchment, reform and transformation: ethnicity and Lebanon's consociational democracy', Democratization 23:7, 1144-1161. 
Norton, A. R. (2014), Hezbollah: A Short History (Princeton, NJ: Princeton University Press).

O'Sullivan, D. (2013), 'Road to proscription: the EU and Hezbollah since the Arab Spring', College of Europe EU Diplomacy Papers 7, 1-34.

Pfeifer, H. (2017), Discursive Struggles over World Order: Exploring Encounters between Islamists and the West (Hamburg: Helmut Schmidt University / University of the Federal Armed Forces, PhD Dissertation).

Salem, P. (2017), 'Lebanon', in E. Lust (ed.), The Middle East: 14th Edition (Electronic iBooks Edition, Thousand Oaks, CA and London: Sage), pp. 1497-1571.

Wählisch, M. and M. Felsch (2016), 'Lebanon and the Arab uprisings: in the eye of the hurricane', in M. Wählisch and M. Felsch (eds), Lebanon and the Arab Uprisings: In the Eye of the Hurricane (Abingdon and New York, NY: Routledge), pp. 1-18.

\section{Interviews and primary sources}

Interview 1 with a journalist from l'Orient le Jour, Baabda (16 March 2015).

Interview 2 with a free journalist and author, Beirut (28 March 2015).

Nasrallah, H. (2011a), Hizbullah SG Sayyed Hassan Nasrallab Speech on Arbaeen of Imam Hussein in Baalbeck (25 January).

Nasrallah, H. (2011b), Speech Delivered by Hizbullah Secretary General Sayyed Hassan Nasrallah on the occasion of the Martyr's Day held by Hezbollah at Sayyed Ashuhada (pbub) Compound in Rweiss (11 November).

Nasrallah, H. (2012a), Speech Delivered by Hizbullah Secretary General Sayyed Hassan Nasrallah during the Ceremony Held to Commemorate the Blessed Birthday of the Holy Prophet Mohammad (Peace be upon him and his Household) and the Islamic Unity Week Held in Sayyed Ashuhada Compound - Rweiss (7 February).

Nasrallah, H. (2012b), Speech Delivered by Hizbullah Secretary General Sayyed Hassan Nasrallah during the Ceremony of Loyalty to the Leader Martyrs (16 February).

Nasrallah, H. (2012c), Political Section of the Speech Delivered by Hizbullah Secretary General Sayyed Hassan Nasrallah during the Ceremony Commemorating the Leader Martyrs' Day Held in Nabi Sheath (24 February).

Nasrallah, H. (2013), Sayyed Nasrallah Delivers Speech on Resistance and Liberation Day (15 May).

Nasrallah, H. (2014a), Full Speech Delivered by Hizbullah Secretary General, His Eminence Sayyed Hassan Nasrallah, via Al Manar Channel Marking the Anniversary of the Martyr Leaders (16 February).

Nasrallah, H. (2014b), Full Speech Delivered by Hizbullah Secretary General, His Eminence, Sayyed Hassan Nasrallah, during al-Quds Day Ceremony held by Hizbullah in Sayyed al-Shuhada Complex in Rweiss (25 July).

Nasrallah, H. (2015a), Full Speech Delivered by Hizbullah Secretary General His Eminence Sayyed Hassan Nasrallah during the Memorial Ceremony in Honor of the Great Quneitra Martyrs Held (30 January).

Nasrallah, H. (2015b), Full Televised Speech Delivered by Hizbullah Secretary General, His Eminence Sayyed Hassan Nasrallah (27 March).

Nasrallah, H. (2015c), Sayyed Nasrallah's Full Speech on April 17 over Yemen (17 April). 
Nasrallah, H. (2015d), Full Speech Delivered by Hizbullah Secretary General Sayyed Hassan Nasrallah on the Day of Resistance and Liberation held in Nabatiyeh (24 May).

Nasrallah, H. (2015e), Full Speech Delivered by Hizbullah Secretary General His Eminence Sayyed Hassan Nasrallah on al-Quds International Day (10 July).

Nasrallah, H. (2015f), Full Speech Delivered by Hizbullah Secretary General, His Eminence Sayyed Nasrallah, in the Ceremony Held to Mark a Week on the Martyrdom of Hassan al Haji in Lweizeh (18 October).

Nasrallah, H. (2016a), Full Speech Delivered by Hizbullah Secretary General, His Eminence Sayyed Nasrallah, on the First Week Commemoration Ceremony Held in Honor of Martyr Leader Ali Abmad Fayyad [Alaa of Bosnia] in Ansar Village (6 March).

Nasrallah, H. (2016b), Full Televised Speech Delivered by Hizbullah Secretary General Sayyed Hassan Nasrallah on al-Quds Day (2 July).

Nasrallah, H. (2016c), Full Speech Delivered by Hizbullah Secretary General, His Eminence Sayyed Nasrallah, during the Memorial Held to Honor Martyr Leader Sayyed Mustafa Badreddine (20 May).

Nasrallah, H. (2016d), Speech Delivered by Hizbullah Secretary General Sayyed Hassan Nasrallah on the Tenth Night of Muharram during the Central Council Held in Sayyed Ashuhada [pbub] Complex (11 November). 
Hanna Pfeifer - 9781526152763 Downloaded from manchesterhive.com at 04/26/2023 12:59:56PM via free access 